\title{
Geochemical Characteristics and Tectonic Significance of the Acidic Volcanic Rocks from the Shetang-Boyang Area, Western Qinling Orogenic Belt, China
}

\author{
Aiai Ma ${ }^{1}$, Hao Guan ${ }^{1}$, Lifei Zou ${ }^{1} \&$ Lanlan Sun ${ }^{1}$ \\ ${ }^{1}$ The School of Earth Science and Resources, Chang'an University, Xi'an, China \\ Correspondence: Aiai Ma, the School of Earth Science and Resources, Chang'an University, Xi'an, 710054, \\ China. E-mail: 1258897291@qq.com
}

Received: June 20, 2016

Accepted: July 12, 2016

Online Published: July 30, 2016

doi:10.5539/esr.v5n2p209

URL: http://dx.doi.org/10.5539/esr.v5n2p209

\begin{abstract}
Acidic volcanic rocks of Shetang-Boyang area are located in the western Qinling orogenic belt, consist of rhyolite and granite porphyry. They are comparable in the chemical composition, enriched in $\mathrm{Si}$, alkali, $\mathrm{Al}$ and a little bit of Mg, Ca and Ti. The contents of HFSE ( $\mathrm{Zr}, \mathrm{Hf}$ ) and LILE (Rb, Th, U) are high, however, the content of $\mathrm{Ba}, \mathrm{Sr}, \mathrm{Ti}, \mathrm{P}$ have obviously depleted and there are obvious negative $\mathrm{Eu}$ anomalies $\left(\mathrm{Eu} / \mathrm{Eu}^{*}=0.06-0.13\right)$. These geochemical characteristics are revealed that these volcanic rocks have an $A_{1}$ type affinity. Geochemical data combined with regional studies, show that these volcanic rocks were formed in a continental extension setting and the western Qinling orogenic belt in $211 \mathrm{Ma}$ has been in the tectonic setting of post-collisional extension.
\end{abstract}

Keywords: Volcanic rocks, Geochemistry, $\mathrm{A}_{1}$ type granite, Post-collisional extension

\section{Introduction}

Shetang-Boyang area in Tianshui city is located in the convergent juncture of the North China block, Qinling orogen, and Yangtz block, and is an important region during the western Qinling orogenic belt tectonic evolution. Previous studies have shown that there are terrestrial acidic volcanic rocks developing in Shetang-Boyang area (Pei et al., 2004; Ding et al., 2005; Lai et al.,2006; Xu et al.,2007), and achieved certain results, however, the geochemistry and tectonic genesis remain controversial. Some scholars believed that the volcanic rocks belong to nonorogenic alkaline rocks, comparable to continental rift type alkaline rhyolite, were formed by partial melting of crustal rocks in continental extension setting, related to sinistral strike-slip shearing of Weihe faulted zone in Early Cenozoic (Pei et al., 2004; Ding et al., 2005.). Some workers suggested that the volcanic rocks were resulted from the Late Triassic under the tectonic setting of post-collisional of the western Qinling orogenic belt (Xu et al., 2007). Much of the debate significantly constrains on better exploring the tectonic evolution of western Qinling orogenic belt. Therefore, based on detailed field investigation, petrography and geochemistry study, this paper has done systematic research of the volcanic rocks and has finally drawn conclusions of the type of the volcanic rock, petrogenesis and tectonic significances. This provides important fundamental data for the tectonic evolution of western Qinling orogenic belt, China.

\section{Geological Settings and Samples}

The study area is located in the north margin of western Qinling orogenic belt, related to the mid segment of the Central orogenic belt, also is the convergent juncture of the North China block, Qinling orogen, and Yangtz block, and is an important region during the western Qinling orogenic belt tectonic evolution (Feng et al., 2003; Sun et al., 2004; Pei et al., 2007 and 2009; Liu et al., 2014; Zhang et al., 2005). Affected by the long-term activity of the Tianshui-Baoji fault, the area has multiple zones of tectonic activity. Since the Meso-Cenozoic, because of the collision between the Indian plate and the Eurasian plate, and the northeast extension of the Qinling-Tibet Plateau, the structures are strongly deformed and strike-slip has widely developed (Zhang et al.,2001; Pei et al., 2004).

The acidic volcanic rocks are composed of lava, tuff, hypabyssal granite porphyry and rhyolite, dominantly occurred at the Shetang-Boyang-Yuanlong- Putaoyuan region with the acreage of $34 \mathrm{~km}^{2}$, extend along a north-south orientation (Fig. 1). The volcanic rocks extend southward to meet the Paleoproterozoic Qinling Group, northward to join Paleozoic Huluhe group, and fault contact with The Indo-Chinese epoch monzogranite. 
The quartze sysenite-porphyry invaded into acidic volcanic rocks and Qinling group.

To ensure the accuracy of the results, four representative samples, including two rhyolites (No.TSP1 and TSP4) and two hypabyssal granite porphyry (No.TSP7 and TSP8) were chosen for studying, and excluded the contaminated samples.

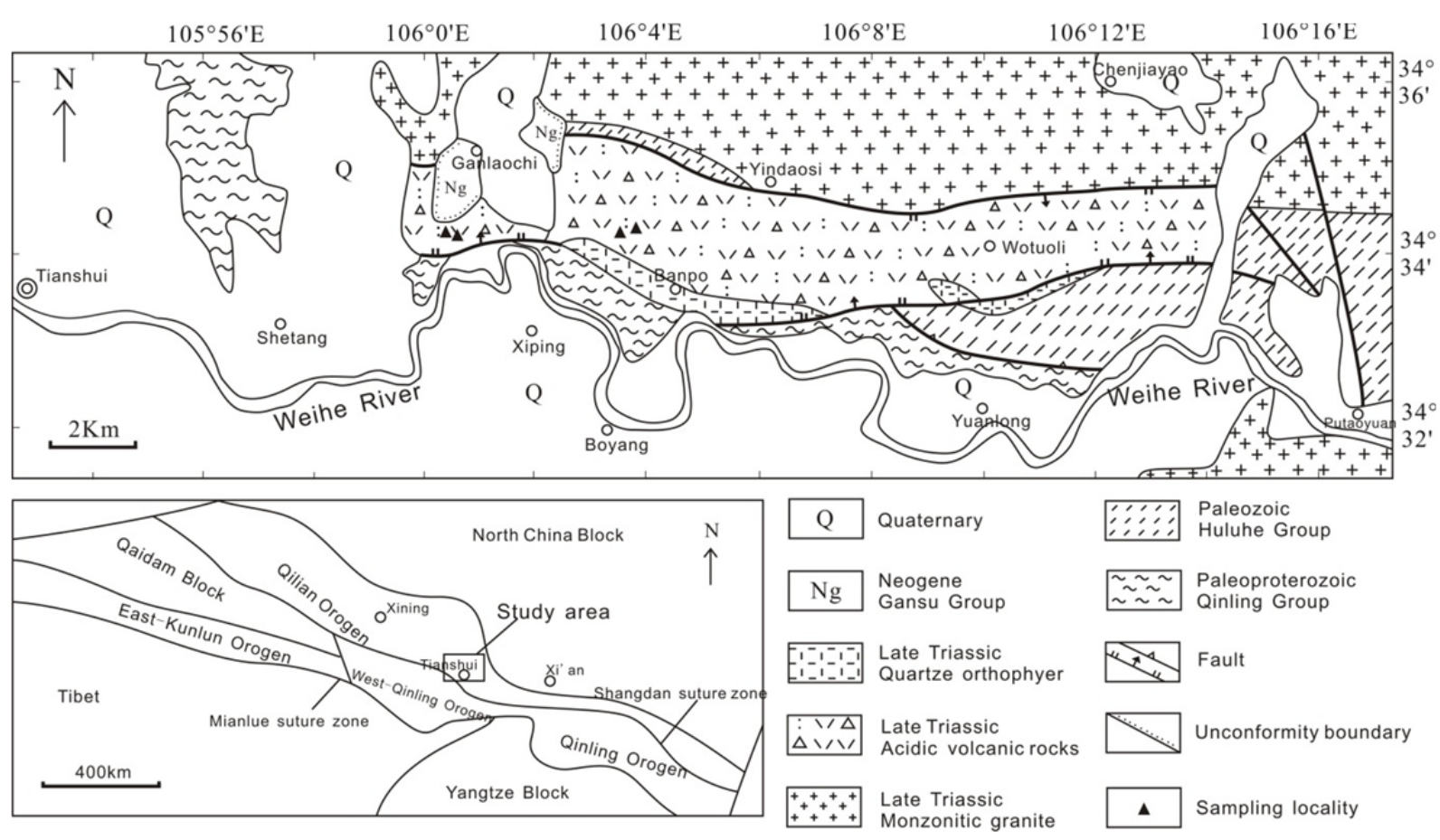

Figure 1. Geological and location maps of the study area (after Pei et al., 2004)

\section{Analytical Methods}

Rocks were grinded into thin sections, and study under the Polarizing microscope, research there optical properties, structure, and ensure the features, genesis of rocks.

Geochemical analyses were undertaken at the Laboratory of Mineralization and Dynamics, Chang'an University (Xi'an, China). The major element compositions were analyzed by X-ray fluorescence spectroscopy (XRF-1500). Trace elements and rare earth elements (REE) were measured by ICP-MS.

\section{Results}

\subsection{Petrography}

Microscopic thin section analysis indicates that the phenocrysts mainly consist of plagioclase, orthoclase and quartz, and the content proportion of the three is nearly the same. The matrixes are quartz-feldspathic, with rhyolitic structure and felsitic texture, and the accessory mineral is corundum.

\subsection{Geochemical Analyses}

Major and trace element compositions of the analyzed samples are listed in Table 1.

\subsubsection{Major Elements}

According to the observation under the microscope and geochemical characteristics, the samples can be divided into two types of granite: rhyolite and granite porphyry.

(1) Rhyolite

The rhyolite samples are enriched in silica $\left(\mathrm{SiO}_{2}\right.$ ranges from $75.11 \%$ to $\left.75.25 \%\right)$, alkalis $\left(\mathrm{Na}_{2} \mathrm{O}+\mathrm{K}_{2} \mathrm{O}=8.38 \%-8.53 \%\right.$ and $\left.\mathrm{K}_{2} \mathrm{O}>\mathrm{Na}_{2} \mathrm{O}\right)$ and $\mathrm{Al}_{2} \mathrm{O}_{3}(12.93 \%-12.94 \%)$, all samples display low $\mathrm{CaO}$ (0.67\%-0.76\%), $\mathrm{MgO}(0.34 \%-0.36 \%)$ and $\mathrm{TiO}_{2}(0.17 \%-0.18 \%)$, but high $\mathrm{FeO}^{\text {tot }} / \mathrm{MgO}(5.75-5.95)$. In the TAS diagram (Le Maritre RWA, 1989), all samples plot within the rhyolite field. The AR (alkalinity ratio) ranging 
from 3.09 to 3.29, $\mathrm{SiO}_{2}$-AR diagram (Wright $\mathrm{J} \mathrm{B}, 1969$ ), all the rhyolite samples plot within the alkaline field (Fig. 2a). The low ANCK [molar $\mathrm{Al}_{2} \mathrm{O}_{3} /\left(\mathrm{CaO}+\mathrm{Na}_{2} \mathrm{O}+\mathrm{K}_{2} \mathrm{O}\right)$ ] values (0.99-1.08) suggest that weakly peraluminous characteristics. All samples are plotted within the weakly peraluminous field in the ANK-ANCK diagram (Fig. 2b). In addition, corundum data in CIPW (Tab. 2) revealed that the rhyolite belongs to aluminous granite rock.

Table 1. Major (\%) and trace element (ppm) of the studied volcanic samples

\begin{tabular}{lllll}
\hline & \multicolumn{3}{l}{ Rhyolite } & \multicolumn{2}{l}{ Granite } & porphyry \\
\cline { 3 - 5 } $\mathrm{Sample}$ & $\mathrm{TSP} 1$ & $\mathrm{TSP} 4$ & $\mathrm{TSP} 7$ & $\mathrm{TSP} 8$ \\
$\mathrm{SiO}_{2}$ & 74.40 & 73.63 & 69.09 & 71.96 \\
$\mathrm{TiO}_{2}$ & 0.17 & 0.18 & 0.32 & 0.25 \\
$\mathrm{Al}_{2} \mathrm{O}_{3}$ & 12.78 & 12.68 & 12.40 & 13.46 \\
$\mathrm{Fe}_{2} \mathrm{O}_{3}$ & 1.74 & 1.75 & 1.87 & 1.81 \\
$\mathrm{FeO}$ & 0.28 & 0.26 & 4.34 & 0.87 \\
$\mathrm{MnO}$ & 0.09 & 0.09 & 0.13 & 0.17 \\
$\mathrm{MgO}$ & 0.34 & 0.35 & 1.25 & 0.60 \\
$\mathrm{CaO}$ & 0.75 & 0.68 & 0.87 & 1.10 \\
$\mathrm{Na} \mathrm{O}_{2} \mathrm{O}$ & 3.61 & 3.41 & 2.87 & 3.07 \\
$\mathrm{~K}_{2} \mathrm{O}$ & 4.68 & 4.95 & 3.31 & 4.88 \\
$\mathrm{P}_{2} \mathrm{O}_{5}$ & 0.03 & 0.04 & 0.07 & 0.07 \\
$\mathrm{LOI}$ & 0.74 & 0.67 & 1.91 & 1.77 \\
$\mathrm{Total}$ & 98.87 & 98.02 & 96.51 & 98.23 \\
$\mathrm{La}$ & 22.51 & 39.36 & 31.78 & 32.81 \\
$\mathrm{Ce}$ & 38.30 & 71.65 & 48.39 & 59.82 \\
$\mathrm{Pr}$ & 4.43 & 7.73 & 6.53 & 6.50 \\
$\mathrm{Nd}$ & 15.61 & 26.78 & 23.27 & 22.68 \\
$\mathrm{Sm}$ & 3.13 & 5.08 & 4.56 & 4.48 \\
$\mathrm{Eu}$ & 0.11 & 0.21 & 0.37 & 0.18 \\
$\mathrm{Gd}$ & 2.52 & 3.86 & 3.64 & 3.54 \\
$\mathrm{~Tb}$ & 0.37 & 0.54 & 0.54 & 0.50 \\
$\mathrm{Dy}$ & 2.13 & 3.02 & 3.09 & 2.79 \\
$\mathrm{Ho}$ & 0.42 & 0.58 & 0.61 & 0.55 \\
$\mathrm{Er}$ & 1.20 & 1.63 & 1.74 & 1.61 \\
$\mathrm{Tm}$ & 0.17 & 0.24 & 0.27 & 0.25 \\
$\mathrm{Yb}$ & 1.01 & 1.42 & 1.59 & 1.48 \\
$\mathrm{Lu}$ & 0.17 & 0.23 & 0.26 & 0.24 \\
$\mathrm{Rb}$ & 133.38 & 233.52 & 91.27 & 196.49 \\
$\mathrm{Sr}$ & 34.89 & 46.31 & 71.91 & 41.73 \\
$\mathrm{Y}$ & 10.88 & 14.02 & 14.90 & 14.50 \\
$\mathrm{Zr}$ & 134.95 & 186.90 & 181.42 & 194.74 \\
$\mathrm{Nb}$ & 20.57 & 29.25 & 20.26 & 29.32 \\
$\mathrm{Cs}$ & 7.08 & 8.78 & 3.75 & 5.93 \\
$\mathrm{Ba}$ & 64.17 & 138.81 & 339.03 & 140.72 \\
$\mathrm{Hf}$ & 3.87 & 5.52 & 4.91 & 5.59 \\
$\mathrm{Ta}$ & 1.25 & 1.81 & 1.28 & 1.80 \\
$\mathrm{Th}$ & 15.04 & 22.19 & 14.25 & 17.17 \\
$\mathrm{U}$ & 3.17 & 4.54 & 4.00 & 5.50 \\
$\mathrm{NREE}$ & 92.08 & 162.33 & 126.64 & 137.43 \\
$\omega_{\mathrm{LREE}} / \omega_{\mathrm{HREE}}$ & 10.53 & 13.09 & 9.79 & 11.54 \\
$\omega(\mathrm{La})_{\mathrm{N}} / \omega(\mathrm{Yb})_{\mathrm{N}}$ & 15.02 & 18.69 & 13.47 & 14.94 \\
$\mathrm{Eu} / \mathrm{Eu}$ & 0.06 & 0.07 & 0.13 & 0.07 \\
\hline & & & & \\
& & & &
\end{tabular}


Table 2. The CIPW of volcanic rocks

\begin{tabular}{llllllllllll}
\hline Sample & $\mathrm{Q}$ & or & $\mathrm{ab}$ & an & $\mathrm{C}$ & Hy en & Hyfs & $\mathrm{mt}$ & he & il & ap \\
\hline TSP1 & 33.88 & 27.98 & 30.85 & 3.6 & 0.47 & 0.85 & 0 & 0.7 & 1.28 & 0.32 & 0.07 \\
TSP4 & 33.65 & 29.87 & 29.41 & 3.19 & 0.56 & 0.9 & 0 & 0.64 & 1.34 & 0.34 & 0.09 \\
TSP7 & 34.63 & 20.29 & 25.1 & 4.06 & 2.75 & 3.25 & 6.34 & 2.8 & 0 & 0.63 & 0.15 \\
TSP8 & 32.91 & 29.4 & 26.46 & 5.15 & 1.27 & 1.53 & 0 & 2.67 & 0 & 0.48 & 0.15 \\
\hline
\end{tabular}

\section{(2) Granite porphyry}

$\mathrm{SiO}_{2}$ contents for granite porphyry samples range from $71.59 \%$ to $73.25 \%$, the total alkali content $\left(\mathrm{Na}_{2} \mathrm{O}+\mathrm{K}_{2} \mathrm{O}\right)$ varies from $6.40 \%$ to $8.09 \%$, and $\mathrm{K}_{2} \mathrm{O}>\mathrm{Na}_{2} \mathrm{O}$, the $\mathrm{Al}_{2} \mathrm{O}_{3}$ ranges from $12.93 \%$ to $12.94 \%$. The granite porphyry also displays low $\mathrm{CaO}(0.90 \%-1.12 \%), \mathrm{MgO}(0.61 \%-1.30 \%)$ and $\mathrm{TiO}_{2}(0.25 \%-0.33 \%)$, but high $\mathrm{FeO}$ tot $/ \mathrm{MgO}$ (4.46-4.96). All the granite porphyry samples also plot within the alkaline field in the $\mathrm{SiO}_{2}$-AR diagram (Fig.2a), and within the weakly peraluminous field in the ANK-ANCK diagram (Fig.2b). Consequently, rhyolite and the granite porphyry have the same characteristics, and may be originate from single magma. According to the geochemical classification scheme for granitoids, the volcanic rocks belong to A-type granites (Fig. 3). Overall, the major element compositions of the volcanic rocks of Shetang-Boyang are comparable to those of A-type granite, as defined by Whalen et al., (1987) and Collins et al., (1982).

\subsubsection{Trace elements}

Rhyolite and granite porphyry originate from single magma, and they have similar characteristics of trace elements, so we analyze them together.

The volcanic rocks are enriched in $\mathrm{Rb}$ (91.27-233.5 ppm), U (3.17-5.50 ppm), Th (14.25-22.19 ppm), and high field strength elements (HFSE) (Zr: 134.95-194.74 ppm; Hf: 3.87-5.59 ppm) and are depleted in Ba (64.17-339.03 ppm) and $\mathrm{Sr}$ (34.89-71.91 ppm), which are similar to A-type granite (Collins et al.,1982; Whalen et al., 1987). In A-type granite discrimination diagrams (Fig. 3), all samples of the volcanic rocks fall in the field of A-type granite. One sample only of rhyolite sample plot in I,S,M, type granite field in the relationship between $1000 \mathrm{Ga} / \mathrm{La}$ with $\mathrm{Zr}$ (ppm), which resulting of low relatively content of $\mathrm{Zr}$ (about $135 \mathrm{ppm}$ ). The volcanic rocks are also enriched in Rare Earth Elements (REE) with total REE concentration of 92.08-162.33 ppm. Chondrite-normalized REE patterns show slight enrichment of Light Rare Earth Elements (LREE) relative to Heavy Rare Earth Element (HREE) with $(\mathrm{La} / \mathrm{Yb})_{\mathrm{N}}$ ratios of 13.58-18.83 and strongly negative Eu anomalies $\left(\mathrm{Eu} / \mathrm{Eu}^{*}=0.06-0.13\right)$ (Fig. 4a). In the element spider diagram (Fig. 4b), the volcanic rocks show negative anomalies of $\mathrm{Ba}, \mathrm{Sr}, \mathrm{P}, \mathrm{Ti}$ and $\mathrm{Eu}$, which agrees with element compositional patterns of A-type granites (Wu et al., 2002). The above geochemical characteristic, show clearly that the volcanic rocks are A-type granite.
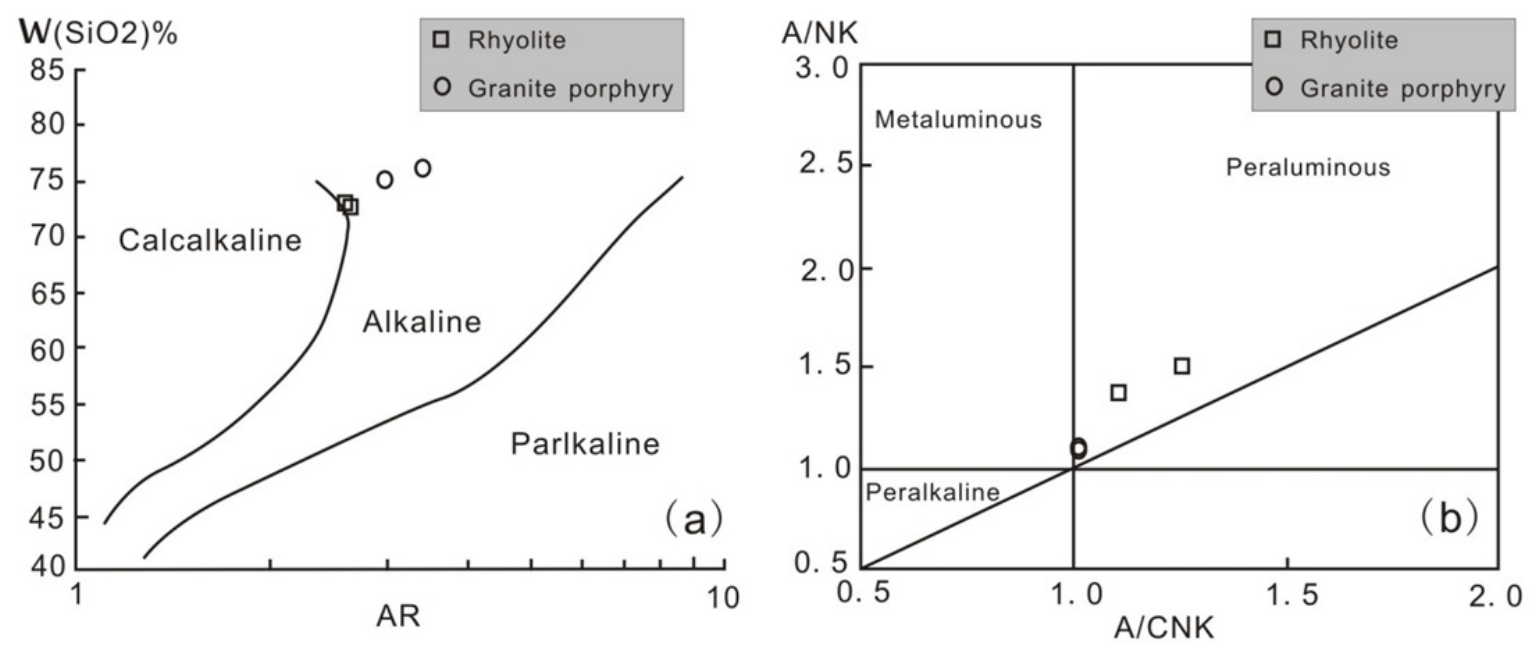

Figure 2. (a) Plots of $\mathrm{SiO}_{2}$ versus AR of the studied samples(after Wright J. B., 1969); (b) A/NK versus A/CNK diagram (after Maniar P D et al., 1989) (The following symbols are the same) 

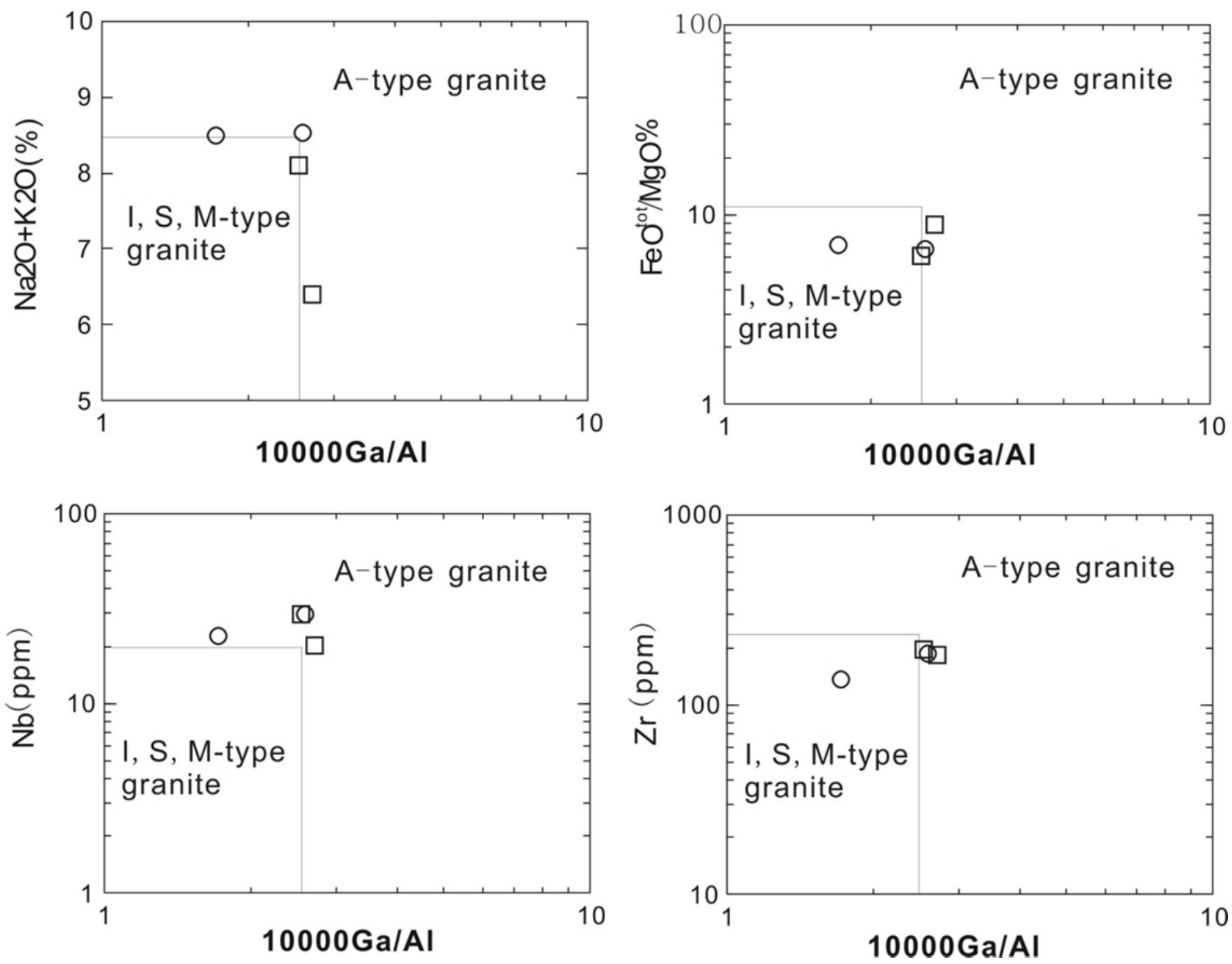

Figure 3. A-type granite discrimination diagram (after Whalen et al., 1987)
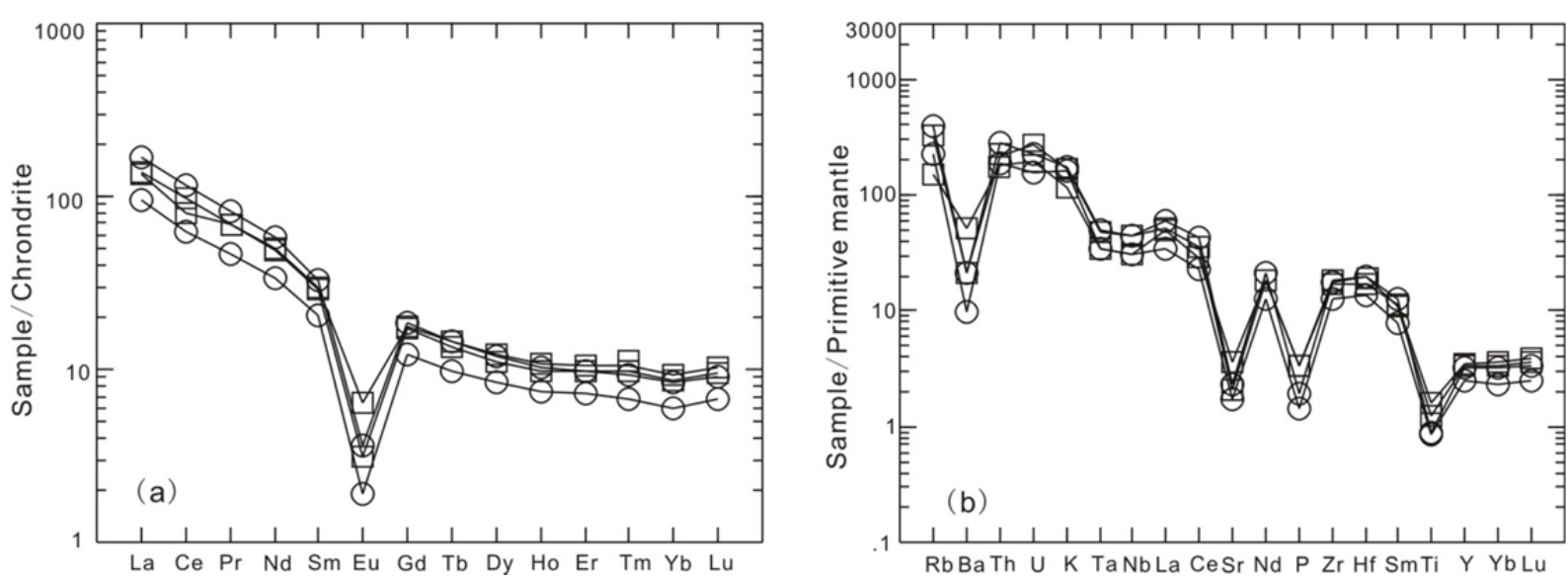

Figure 4. (a) Chondrite-normalized REE patterns; (b) primitive mantle-normalized element spider diagram of volcanic rocks

Note. The normalizing values from Sun \& McDougall (1989)

\section{Discussion}

\subsection{Tectonic Setting}

Eby (1992) subdivided A-type granites into $A_{1}$ and $A_{2}$ subgroup. These two types have different sources and 
tectonic setting. The $A_{1}$ group occurs in an orogenic setting such as continental rifts or intraplate environments, and their magmas are derived from sources like those of oceanic-island basalts. The $\mathrm{A}_{2}$ group forms in a broader range of environments, and those emplaced at the end of a long period of apparently high heat flow and granitic magamatism. The $\mathrm{A}_{2}$ group magmas were derived from continental crust or underplated crust that has experienced a cycle of continent-continent collision or island-arc magmatism (Zhang et al., 2007). The $\mathrm{A}_{1}$ and $\mathrm{A}_{2}$ groups can be discriminated using the Y-Nb-Ce andY-Nb-3*Ga diagrams (Fig. 5(a)). As shown in Figure 5(a), all samples fall into the $A_{1}$ group, suggesting a continental rifts or intraplate environments.

\subsection{Geodynamic Implications}

In this paper, the rhyolite and granite porphyry have a similar chemical composition (see above) and formed in a continental rifts or intraplate environments. In the $\mathrm{Rb}$ vs $\mathrm{Yb}+\mathrm{Ta}$ tectonic discrimination diagram of Pearce et al. (1984) volcanic rocks fall into the field of "within plate granite" (Fig. 5(b)), indicate that the rocks were formed in a continental extension setting.

Combined with previous studies, the Qinling orogenic belt, being part of the central orogenic belt in China, was sutured to the Yangtz block during the middle to late Triassic (Li et al., 2009 and 2010), and the end period of Indo-China Movement in Qinling is characterized by changing from continental crust thickened to lithosphere mantle adjusting or crust thining (Zhang et al., 2001; Zhang et al., 1995; Zhang et al., 1996, 1997), Gong et al. (2009) proposed that the tectonic event of transition from lithospheric extrusion to extension in Qinling orogenic belt, may generated in range of 224-210Ma. Moreover, Xu et al. (2007) zircon U-Pb dating yields ages of $211 \mathrm{Ma}$ for magma crystallization, corresponding to the end period of Indo-China Movement, $\mathrm{Pb}$ isotopic data suggest an impossible source of the North Qinling basement rocks for rhyolites. Therefore, the western Qinling orogenic belt in 211Ma has been in the tectonic setting of post-collisional extension.

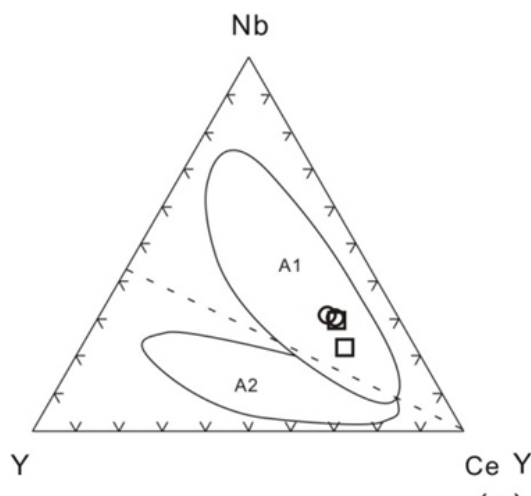

(a)

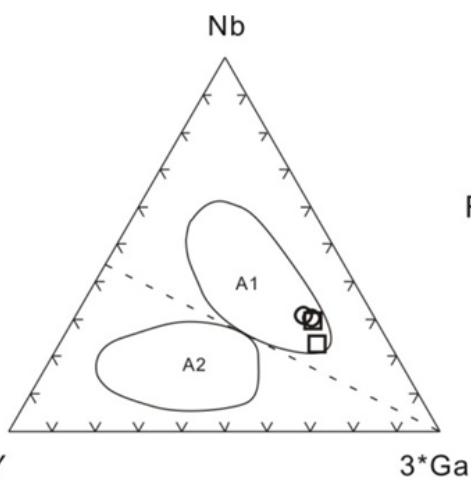

$3^{\star} \mathrm{Ga}$

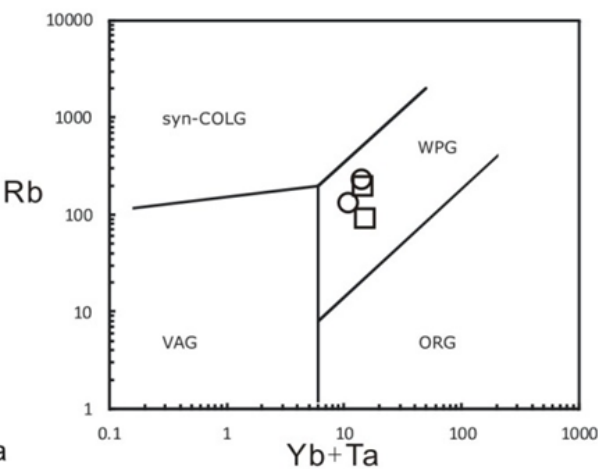

(b)

Figure 5. (a) $A_{1}$ and $A_{2}$ subgroup discrimination of A-type granite (after Eby, 1992); (b) Rb-Y+Nb and Nb-Y diagram of volcanic-subvolcanic rocks (after Pearce et al., 1984)

Note. Syn-COLG-syn-collision granite; VAG-volcanic arc granite; WPG-within plate granite; ORG-ocean ridge granite.

\section{Conclusions}

The rocks are $\mathrm{A}_{1}$-type granite, including one rhyolite and three granite porphyry, and formed in a continental extension setting, combined with previous studies, we consider that the western Qinling orogenic belt in $211 \mathrm{Ma}$ has been in the tectonic setting of post-collisional extension.

\section{Acknowledgments}

This study is funded by China Geological Survey (No.1212011120100, 1212011120099).

\section{References}

Collins, W. J., Beams, S. D., White, A. J. R., \& Chappell, B. W. (1982). Nature and origin of A-type granites with particular reference to southeastern Australia. Contrib. Mineral. Petrol. 80, 189-200. http://dx.doi.org/10.1007/BF00374895

Ding, S. P., Pei, X. Z., \& Hu, B. (2005). Geochemical Characteristics and Origin of Cenozoic Acid Volcanic 
Rocks in the Tianshui Area, Gansu Province. Geology and Prospecting, 41(1), 33-37. http://dx.doi.org/ http://dx.doi.org/10.3969/j.issn.0495-5331.2005.01.007

Eby, G. N. (1992). Chemical subdivision of the A-type granitoids: Petrogenetic and tectonic implications. Geology, 20, 641-644. http://dx.doi.org/10.1130/0091-7613(1992)020<0641:CSOTAT >2.3.CO;2

Feng, Y. M., Cao, X. D., \& Zhang, E. P. (2003). Tectonic Evolution Framework and Nature of the West Qinling Orogenic Belt. Northwestern Geology, 36(1), 1-10. http://dx.doi.org/10.3969/j.issn.1009-6248.2003.01.001

Gong, H. J., Zhu, L. M., Sun, B. Y., Li, B., \& Guo, B. (2009). Zircon U-Pb age and Hf isotope characteristics and their geological significance of the Shahewan, Caoping and Zhashui granitic plutons in the South Qinling orogen. Acta Petrologica Sinica, 25(2), 248-264. Retrieved from http://www.cnki.com.cn/Article/CJFDTotal-YSXB200902002.htm

Lai, S. C., Zhang, G. W., \& Qin, J. F. (2006). Geochemistry and Petrogenesis of the Tertiary Rhyolite from the Boyang Area, Northeastern Margin of the Qinghai Tibet Plateau. Earth Science Frontiers, 13(4), 212-220. http://dx.doi.org/10.3321/j.issn:1005-2321.2006.04.019

Liu, C. J., Pei, X. Z., \& Li, Z. C. (2014). Moshigou Meta-Basalt in the Tianshui Area in the Conjunction of the Qinling-Qilian Orogens: Zircon U-Pb Geochronology, Geochemistry and Tectonic Implications. Acta $\begin{array}{lllll}\text { Geologica Sinica, } & \text { 88(3), } & \text { 347-360. } & \text { Retrieved }\end{array}$ http://www.cnki.com.cn/Article/CJFDTotal-DZXE201403005.htm

Li, S. Z., Kusky, T. M., Liu, X. C., Zhang, G. W., Zhao, G. C., Wang, L., \& Wang, Y. J. (2009). Two-stage collision-related extrusion of the western Dabie HP-UHP metamorphic terranes, central China: evidence from quartz c-axis fabrics and microstructures. Gondwana Research, 16, 294-309. http://dx.doi.org/10.1016/j.gr.2009.03.003

Li, S. Z., Kusky, T. M., Zhao, G. C., Liu, X. C., Zhang, G. W., Kopp, H., \& Wang, L., (2010). Two-stage Triassic exhumation of HP-UHP terranes in the Dabie orogen of China: constraints from structural geology. Tectonophysics, 490, 267-293. http://dx.doi.org/10.1016/j.tecto.2010.05.010

Le Maitre, L., \& R, W. A. (1989). Classification of Igneous Rocks and Glossary of Terms, Recommendations of the International Union of Geological Sciences Subcommission on the Systematics of Igneous Rocks. Blackwell Scientific Publications.

Maniar, P. D., \& Piccoli, P. M. (1989). Tectonic discrimination of granitoids. Geol Sco Am Bull, 101, 635-643. http://dx.doi.org/10.1130/0016-7606(1989)101<0635:TDOG>2.3.CO;2

Pearce, J. A., Nigel, B. W., \& Andrew, G. (1984). Trace element discrimination diagrams for the tectonic interpretation of granitic rocks. J. Petrol, 25(4), 956-983. http://dx.doi.org/10.1093/petrology/25.4.956

Pei, X. Z., Ding, S. P., \& Hu, B. (2004). Geochemical Characteristics and Tectonic Significance of Cenozoic Acid Volcanic Rocks in Tianshui area, West Qinling Mountains. Acta Petrologica Et Mineralogica, 23(3), 227-235. http://dx.doi.org/10.3969/j.issn.1000-6524.2004.03.004

Pei, X. Z., Ding, S. P., \& Zhang, G. W. (2007). Zircons LA-ICP-MS U-Pb Dating of Neoproterozoic Granitoid Gneisses in the North Margin of West Qinling and Geological Implication. Acta Geologica Sinica, 81(6), 772-786. http://dx.doi.org/10.3321/j.issn:0001-5717.2007.06.005

Pei, X. Z., Ding, S. P., \& Li, Z. C. (2009). Early Paleozoic Tianshui-Wushan Tectonic zone of the Northern Margin of West Qinling and its Tectonic Evolution. Acta Geologica Sinica, 83(11), 1547-1564. http://dx.doi.org/10.3321/j.issn:0001-5717.2009.11.002

Sun. S. S., \& McDonough, W. F. (1989). Chemical and isotopic systematics ofoceanic basalts: Implications for mantle composition and processes. In: Saunders AD and Norry MJ (Eds.). Magmatism in the Ocean Basins. (Reprinted from Geological Society of London : Special Publication, 42, 313-345. http://dx.doi.org/10.1144/GSL.SP.1989.042.01.19)

Sun, Y. G., Zhang, G. W., \& Wang, J. (2004). 40Ar/39Ar Age of the Basic Sill Swarms of Two Periods in the Junction Area of Qinling and Kunlun and Its Tectonic Significance. Acta Geologica Sinica, 78(1), 65-71. http://dx.doi.org/10.3321/j.issn:0001-5717.2004.01.008

Whalen, J. B., Currie, K.L., \& Chappell, B.W. (1987). A-type granites: geochemical characteristics, discrimination and petrogenesis. Contrib. Mineral. Petrol. 95, 407-419. http://dx.doi.org/10.1007/BF00402202

Wright, J. B. (1969). A simple alkalinity ratio and its application to question of non-orogenic granite genesis. 
Geol. Mag., 106(4):370-384. http://dx.doi.org/10.1017/S0016756800058222

Wu, F. Y., Sun, D. Y., Li, H. M., Jahn, B. M., \& Wilde, S. (2002). A-type granites in northeastern China: age and geochemical constraints on their petrogenesis. Chem. Geol. 187, 143-173. http://dx.doi.org/10.1016/S0009-2541(02)00018-9

Xu, X. Y., Wang, H. L., Chen, J. L., Su, X. H, Wu, P., \& Gao, T. (2007). Zircon U-Pb Age, Element Geochemistry of Mesozoic Acid Volcanic Rocks at Yindaoshi Area in Western Qinling. Acta Petrologica Sinica, 23(11), 2845-2856. http://dx.doi.org/10.3969/j.issn.1000-0569.2007.11.015

Zhang, B. R., Zhang, H. F., \& Xu, J. F. (1995). The application of isotope geochemical survey and chemical geodynamics in the study from east Qinling Orogenic Belt. Earth Sciences, 20(5), 551-556. Retrieved from http://epub.cnki.net/kns/default.htm

Zhang, G. W., Zhang, B. R., Yusn, X. C., \& Xiao, Q. H. (2001). Qinling Orogenic Belt and Continental Dynamics. Beijing: Science Press, 1-855.

Zhang, H. F., Zhang, B. R., \& Zhao, Z. D. (1996). Subduction and collision of continental crust in Shangdan suture form East Ailing; Evidence form isotopic tracing for the source of granitic magma. Science in China $\begin{array}{lllll}\text { (Series D), 231-236. } & \text { 26(3), } & \text { Retrieved }\end{array}$ http://www.cnki.com.cn/Article/CJFDTOTAL-JDXK199603005.htm

Zhang, H. F., Zhang, B. R., \& Zhao, Z. D. (1997). Pb isotope in feldspar of granitic rocks and its tectonic significance in East Qinling orogenic belt. Acta Geologica Sinica, 71(2), 142-149. Retrieved from http://www.cnki.com.cn/Article/CJFDTotal-DZXE199702005.htm

Zhang, H. F., Randall Parrish, Zhang, L., Xu, W. C., Yuan, H. L., Gao, S., \& Quentin, G. Crowley (2007). A-type granite and adakitic magmatism association in Songpan-Garze fold belt, eastern Tibetan Plateau:

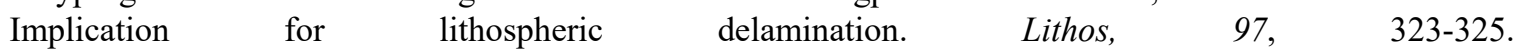
http://dx.doi.org/10.1016/j.lithos.2007.01.002

Zhang, X. H., Liu J. H., \& Xu, J. L. (2005). Second Study on Plate Tectonics in Gansu Province. Acta Geologica Gansu, 14(2), 1-10. Retrieved from http://www.cnki.com.cn/Article/CJFDTOTAL-GSDZ200502000.htm

\section{Copyrights}

Copyright for this article is retained by the author(s), with first publication rights granted to the journal.

This is an open-access article distributed under the terms and conditions of the Creative Commons Attribution license (http://creativecommons.org/licenses/by/4.0/). 